\title{
Behaviour Intention Among Property Developer Employees to Adopt Technology Application at Workplace
}

\section{Haliza binti Mohd Said, Ahmad Feruz bin Izharuddin, Irena binti Idris, and Hezrizah binti Othman}

Faculty of Business and Technology, UNITAR International University, Management Department, Selangor, Malaysia

\section{Abstract}

Introduction. Many researchers have highlighted factors that influence people in adopting new applications at the office. Based on past studies, there is a questionable issue of what really effect employees from adopting a system in their daily work activities. The purpose of this research is to identify the behaviour intention among employees in adopting technology application at work. The specific objective of the research is to identify the relationship between Perceived Usefulness, Perceived

Received: 18 January 2019 Accepted: 24 March 2019 Published: 31 March 2019

Publishing services provided by Knowledge E

(c) Haliza binti Mohd Said et al. This article is distributed under the terms of the Creative Commons Attribution License, which permits unrestricted use and redistribution provided that the original author and source are credited.

Selection and Peer-review under the responsibility of the First ELEHIC Conference Committee. Ease of Use, Enjoyment and Computer Self-Efficacy towards Behavioural Intention to adopt online technology application among employees at the workplace. Method. A quantitative research design is deployed in this research. A purposive sampling was used to collect data at the property developer premises. A total of 200 respondents were asked to rate questionnaire using 5 Likert-scale instruments. Results. The research findings show that Perceived Usefulness, Perceived Ease of Use, Enjoyment and Computer Self-Efficacy have a significant relationship towards the employees' behavioural intention to use the online technology application at their workplace.

Keywords: Perceived Usefulness, Perceived Ease of Use, Enjoyment, Computer Self-Efficacy, Behaviour Intention

\section{Introduction}

The adoption of electronic HRM in the daily HR activities has brought about a significant impact on organizational effectiveness and efficiency [1]. With such change, the shape of administrative matters in organizations is taking a pace of change with the intention to reach the optimum productivity level, especially in human resource management as new technologies are supposed to add value and bring about efficiency and empowerment 
In fact, electronic HRM's implementation in organizations has the ability to promote sustainability as it reduces negative environmental, social and economic consequences [3]. This further reduces environmental waste, social waste, and economic waste. Success in today's hypercompetitive markets depends less on advantages associated economies of scale, technology and access to capital; and more on innovation, speed, and adaptability [4]. But such usage depends on the behavioral intention of users to use electronic applications as there are factors that contribute to the employees' acceptance in adapting to this new electronic environment which could hinder their performance towards productivity of the organization. Terzis and Economides [5] have found among others how behavioral intention has significantly attributed to perceived usefulness and perceived ease of use as they have studied the acceptance and use of computer-based assessment in the research.

\subsection{Background of study}

Being one of the top Government Linked Company property developers of Selangor, Perbadanan Kemajuan Negeri Selangor or known as PKNS has always put productivity as a priority in operating its core business ever since its establishment in 1964. It welcomes approaches that could enhance any time-consuming process in order to increase the productivity and most importantly to remain relevant in the property market that always demanding and revolving. One of the ways as to improve the productivity is through the enhancements of the existing human resource management electronically that could bring success to the organization. Such introduction of Electronic Human Resource Management (EHRM) in any organization is expected to facilitate a more efficient and strategic way of working for Human Resource (HR) professionals. In facts, Shrivastava and Shaw [6] stated that the Electronic Human Resource Management (EHRM) provides HR functions with the opportunity to create new avenues for contributing to the organizational success and such success is contributed and directly related to the productivity. Thus, it shows that the performance of an organization relates to the productivity of the workforce within the organization itself. This was confirmed that stated greater use of EHRM practices directly leads to an improvement in labor productivity [7].

There are many ways and methods to increase productivity at the various level of professionalism in any organizations. As for PKNS, Enterprise Web Based Access Attendance Automation Control and Security System (EWACS) application is one of them. Using this electronic tool could help employees to fill up and monitor records and retrieval throughout any duration of their leave applications without much time spent 
as everything is fast through a click of a finger. As for HR Department, employees' movements within working hours and the working records could be monitored through intranet service, conveniently faster and reliable and most important, at anytime and anywhere within the PKNS office building without the use of paper. But in order for employees to contribute towards productivity via the electronic application, such application should be well received and trusted before being adopted.

Failure to use such electronic application in PKNS would affect the employee's performance in terms of inefficient and ineffective output that will lead to lower productivity due to time lost and time-consuming activities, backlogging in decision making and cost-wasting activities. Currently, there is already an outcry among the employees towards the EWACS application that has been implemented ever since PKNS moved to its new green building in 2016. Despite moving to the new application which incorporates multiple modules that is accessible to all levels of staff, such application simply does not receive a warm welcome as it invites unfriendliness, uncertainty, and hesitation among the users. With such vague and discomfort situation, this would halt and reciprocate the actual purpose use of using EWACS in terms of optimization and spent cost over the purchase of such application. This is not in line with PKNS shared values of "Pelanggan Diutamakan" (Customers First); "Komited Ke Arah Kecemerlangan" (Committed to Excellent), "Nilai Professional" (Professional Values), and "Sinergi Berpasukan" (Team Synergy). Without these, achieving the vision and mission of PKNS as one of the Government Linked Company of the Selangor state will look uncertain and pointless.

Concurrently, the application of EWACS is in line with PKNS Quality commitment to MS ISO 14001:2015 towards a sustainable environment that stresses in protecting the environment for the future generation. This study will help PKNS to understand the reasons behind such reluctance among PKNS staff at all level towards EWACS application and what the users want or expect from the application. It is hoped that Human Resource Department will work towards improving and upgrading the existing features of EWACS as to make full use of it, that finally contribute for better productivity of the organization while optimizing the needs of the stakeholders. This research identifies factors that contributed to employees' intention to adopt electronic application at work place. This is critical as it indirectly results in better productivity and sustainability of the organization. Without such exploration, the push factors that encourage PKNS staff to use EWACS may not be determined as employees may not be interested in using such an electronic application. 


\subsection{Research questions}

The research questions for this research are as follows:

1. Does Perceived Usefulness (PU) have relationship towards using EWACS System among PKNS employee?

2. Does Perceived Ease of Use (PEOU) have relationship towards using EWACS System among PKNS employee?

3. Does Enjoyment have relationship towards using EWACS System among PKNS employee?

4. Does Computer Self Efficacy have relationship towards using EWACS System among PKNS employee?

\subsection{Research objectives}

The main research objective is to identify the factors that is related to employees' behavior in adopting EWACS System as part of the organization needs. By doing this, it will help the employer to understand the shortcomings of the existing system thus to accommodate better facilities towards the system usage in promoting works efficiency. The specific objectives are;

1. To determine the relationship between Perceived Usefulness (PU) towards Behavioral Intention (BI) in using EWACS system.

2. To determine the relationship between Perceived Ease of Use (PEOU) towards Behavioral Intention (BI) in using EWACS system.

3. To determine the relationship between Enjoyment (ENJ) towards Behavioral Intention (BI) in using EWACS system.

4. To determine the relationship between Computer Self Efficacy (CSE) towards Behavioral Intention (BI) in using EWACS system.

In order for employees to contribute towards greater productivity via an electronic application, such application should in the first place needs to be well received, accepted and trusted before being adopted for regular use. This is in line with Sargolzaei [8] which states that for technologies to improve productivity, they must be accepted and used by users that can be members of the external user such as the citizen. Adding 
to this, EHRM can enable the organization to improve labor productivity by performing HR activities quicker than traditional practices and enabling non-HR employees to focus on core duties [9-11]. This was later confirmed by Al-Hmouze [12] that application of electronic human resources has a positive effect on raising the efficiency of companies, giving the company a competitive advantage through quick adaptation to external changes. Through the electronic application of paperless working environment, less dependency on manual entry is available and this will decrease the reliance on paper for copying, printing and storing which turn out to be a reduction in cost. In the long run and from the environmental aspect, this directly preserves natural resources, prevent pollution and reduce wastage and energy for the sake of the future generation [13].

\section{Literature Review}

\subsection{Perceived usefulness (PU)}

As stated by Davis [18], Perceived Usefulness refers to the enhancement of job performance through a particular system. In order to create such enhancements, the users need to have a driver that initiate the sense of liking to use the new system which is Behavior Intention. Dohan and Tan [14] in his study through meta-analysis Research Paper has concluded that there is a strong relationship between Perceived Usefulness and Behavior Intention. With this Behavior Intention, it helps to shape the use on such electronic application as Elkaseh, Wong and Fung [15] discovered how an electronic application impacts user through the Perceived Usefulness in which when the application is simple and easy to use, the users will have more intention to use electronic application. Simply put, individuals who feel the application is more useful and users will have more intention to use the application.

\subsection{Perceived ease of use (PEOU)}

Perceived Ease of Use has been widely accredited by many researchers for its role as a determinant towards Behavioral Intention to use technology. Among them are Abdullah, Jayaraman, Shariff, Bahari, and Nor [16] and Li, Ganeshan, and Xu, [17]. Abdullah et al., [16] state that individuals' technology adoption could be estimated based on their intentions which is influenced by a preconceived idea on easiness and usefulness of an application. While Li et al., [17] states how the factor "ease of use", along with other factors, facilitates an application of e-learning process among users. In PKNS EWACS 
application context, this could lead to more staff will be using it with ease and effortlessly. Undeniably, the roles of these both two basic constructs have a great impact on the succession of online application implementation as proven by many scholars.

Davis [18] firstly suggested that the actual use of a system is behavior and that only two beliefs would influence the users that are PU and PEOU. Davis [18] even had exposed how Behavioral Intention to use technology is influenced by these two constructs where users can either respond favorably or unfavorably towards engaging the EHRM system. It was further discovered that PEOU has a significant relationship with PU because a system that appears easier to use will be regarded as more useful [19]. Another finding by Abdullah, Ward and Ahmed, [20] is that upon completing an online survey questionnaire, PU and PEOU were among the important factors that should be considered in the implementation of the electronic application. Nor Redzuan et al., [21] highlighted EHRM needs to be equipped with good characteristics like friendly-approach, flexible and with examples in order to induce the perspective of Perceived Usefulness and Perceived Ease of Use, thus getting the attention of the employees' intention to use EHRM.

\subsection{Enjoyment (ENJ)}

The external factor of Enjoyment (ENJ) plays an important role in the online application. The main issue about the relation between Enjoyment towards Behavior Intention is whether ENJ is influenced by the user's intention to use. Nusair and Kandampully [22] defined ENJ as the device that attracts the attention of the online system users with enjoyable inputs that is essential in attracting, satisfying and retaining users. Yi and Hwang [23] has investigated the actual use of Blackboard (an online application) by university students and found the important role of ENJ as a positive influence on the decision of students (respondents) to use Blackboard and subsequently on the actual use. While Goetz et al., [24] showed that ENJ has a clear linkage to learning behaviors such as self-regulated learning and creative problem-solving, the discovery by Alenezi, Karim, and Veloo [25] has revealed that users of students at Saudi Arabian Universities with higher perceived enjoyment towards e-learning would have better intention for elearning activities as it has significant influenced their intention to use e-Learning.

\subsection{Computer self-efficacy (CSE)}

Previous studies show that self-efficacy played a vital role in explaining the adoption of e-learning technologies or system [26-28]. Computer Self Efficacy (CSE) refers to 
one's belief about his/her ability to accomplish a particular task using the computer Jia \& Eder [29]. It attracts user's behavior towards using a computer as individuals in the high level of CSE will be confident in their capability to overcome any difficulties when using computers. While Terzis and Economides [5] had investigated the factors that impact the Behavioral Intention to Use a computer in which Perceived Ease of Use (PEOU) was found to have significantly attributed to Computer Self Efficacy (CSE) and Perceived Usefulness (PU) was significantly attributed among others to Perceived Ease of Use (PEOU). But there are journals that describe the relationship between self-efficacy and perceived usefulness with different results. Studies like by Al-Ammary, Al-Sherooqi, and Al-Sherooqi, [30]; Chow, Cho, and Chan, [31]; Al-Mushasha, [32] found that there were significant positive relationships between self-efficacy and perceived usefulness of computer.

The study by Al-Ammary et al., [30] confirmed that perceived usefulness and perceived ease are vital factors for predicting the students' behavioral intention to use social networks as learning tools at the University of Bahrain. While Chow et al., [31] suggested that with computer self-efficacy was taken as the external variable, the system under their study was perceived as useful giving the respondents confident working with computers but they remained neutral regarding the ease of use of the system. Besides that, the results of a study by Al-Mushasha, [32] suggested that perceived usefulness, perceived ease of use and computer self-efficacy is among important determinants of elearning acceptance in a higher education environment. But at the same time, Ma, Chao and Cheng, [33] indicated there was a lack of significant association between the two constructs of self-efficacy (SE) and perceived usefulness (PU) with relating TAM with elearning system. They discovered that CSE has a direct effect on the PU and an indirect influence on the behavioral intention to use e-learning system.

\subsection{Theoretical underpinning theory}

Technology Acceptance Model (TAM) proposed and originated by Davis [18] is used for this project paper as shown in Figure 1. This model provides a basis for tracing the impact of external variables on internal factors of belief, attitudes, and intention with two most important constructs that is Perceived Usefulness (PU) and Perceived Ease of Use (PEOU). TAM was tailored to Information System (IS) contexts and was designed to predict information technology acceptance and usage on the job.

But TAM was firstly modified by Davis, Bogozzi and Warshaw, [34] as shown in Figure 2 which introduced "Attitude" as a mediator towards Behavioral Intention. 


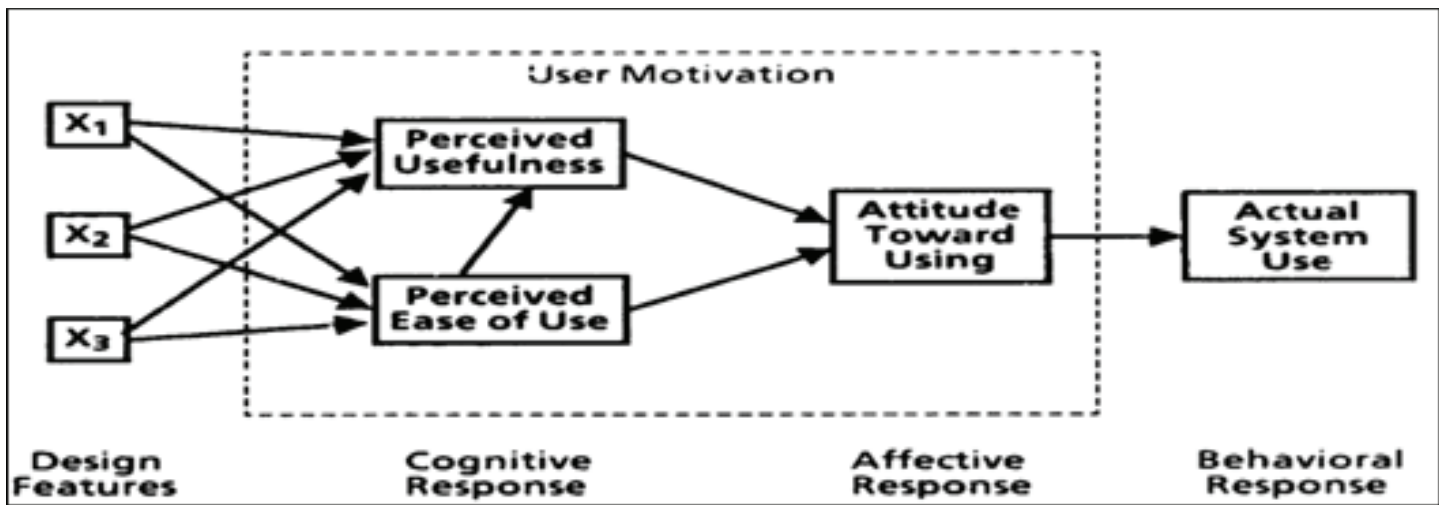

Figure 1: Original Technology Acceptance Model (Davis. 1986).

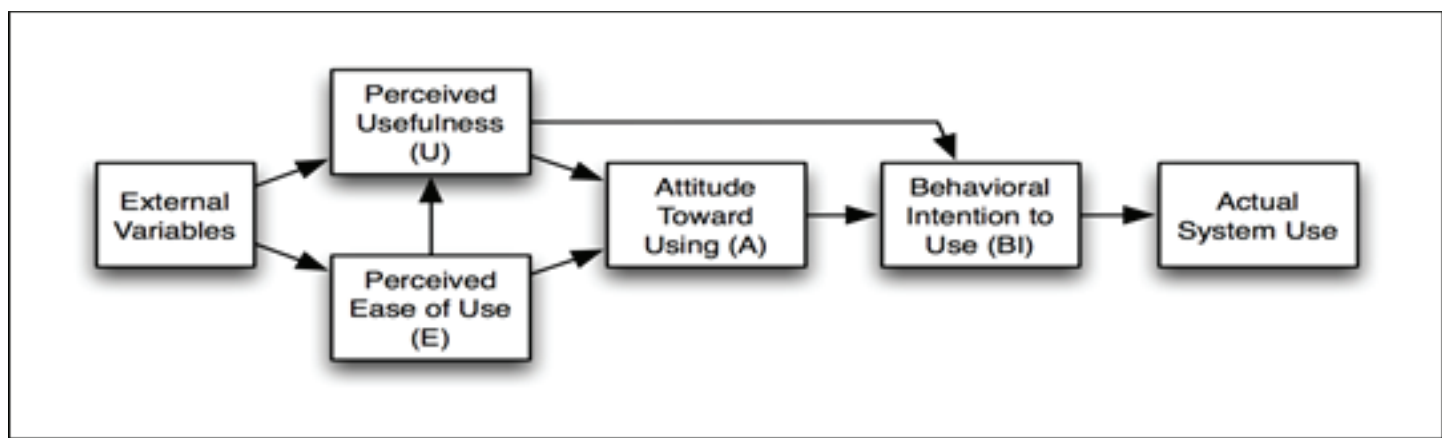

Figure 2: Modified Version of TAM (Davis, Bogozzi and Warshaw, 1989).

The final TAM version was introduced by Venkatesh and Davis [18] after the main finding of both PU and PEOU found to have a direct influence on behavior intention thus eliminating the need for the attitude construct as shown in Figure 3. TAM has been extended to accommodate a diverse set of technologies and users that is TAM 2 and TAM 3 as it excluded the attitude construct to explain more on intention.



Figure 3: Final Version of TAM.

Under this study, TAM 3 is adopted as shown in Figure 4 as it presents a complete nomological network of determinants of individuals' IT adoption and use [35]. Whilst based on Davis et al., [19] there was a strong evidence to support a direct relationship between behavioral intention and actual system usage, displacing the attitude construct 
as an intervening variable. In fact, PU and PEOU are two profound factors including Behavioral Intention hence override the need for attitude construct.

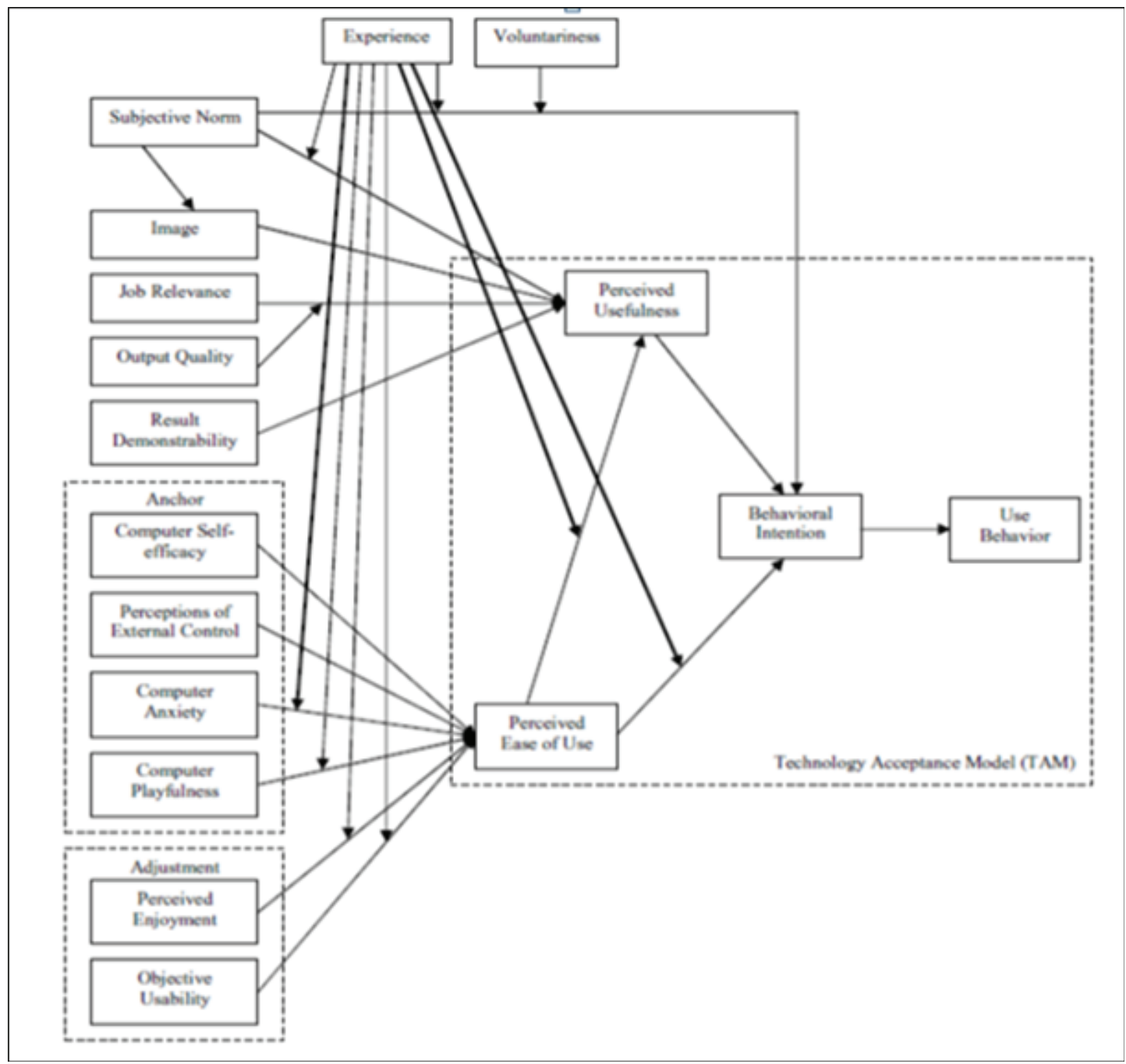

Figure 4: Technology Acceptance Model 3 (TAM 3).

Though attitude factor was included in original TAM as the mediator between user perception (i.e. PU and PEOU) and Behavioral Intention (BI), there were also studies that exclude Attitude from the model because of its weak role between the construct [20]. In fact, Liu [36] removed Attitudes from TAM as it can provide a better understanding of the effects of PU and PEOU on the BI construct. Therefore, Attitude is not considered in this project. Simultaneously, the construct items under TAM 3 are suitable and applicable to PKNS present working environment within a large population as PKNS currently has a total of 1,066 employees.

Out of all constructs in TAM 3 model, this study only considers PU, PEOU, ENJ, and CSE as Independent Variables and Behaviour Intention of using EWACS as Dependent Variable as it is practically linked to the existing situation of PKNS. 


\subsection{Proposed research framework}

Based on the past literature and underpinning theory, the proposed research framework is illustrated as Figure 5 below:

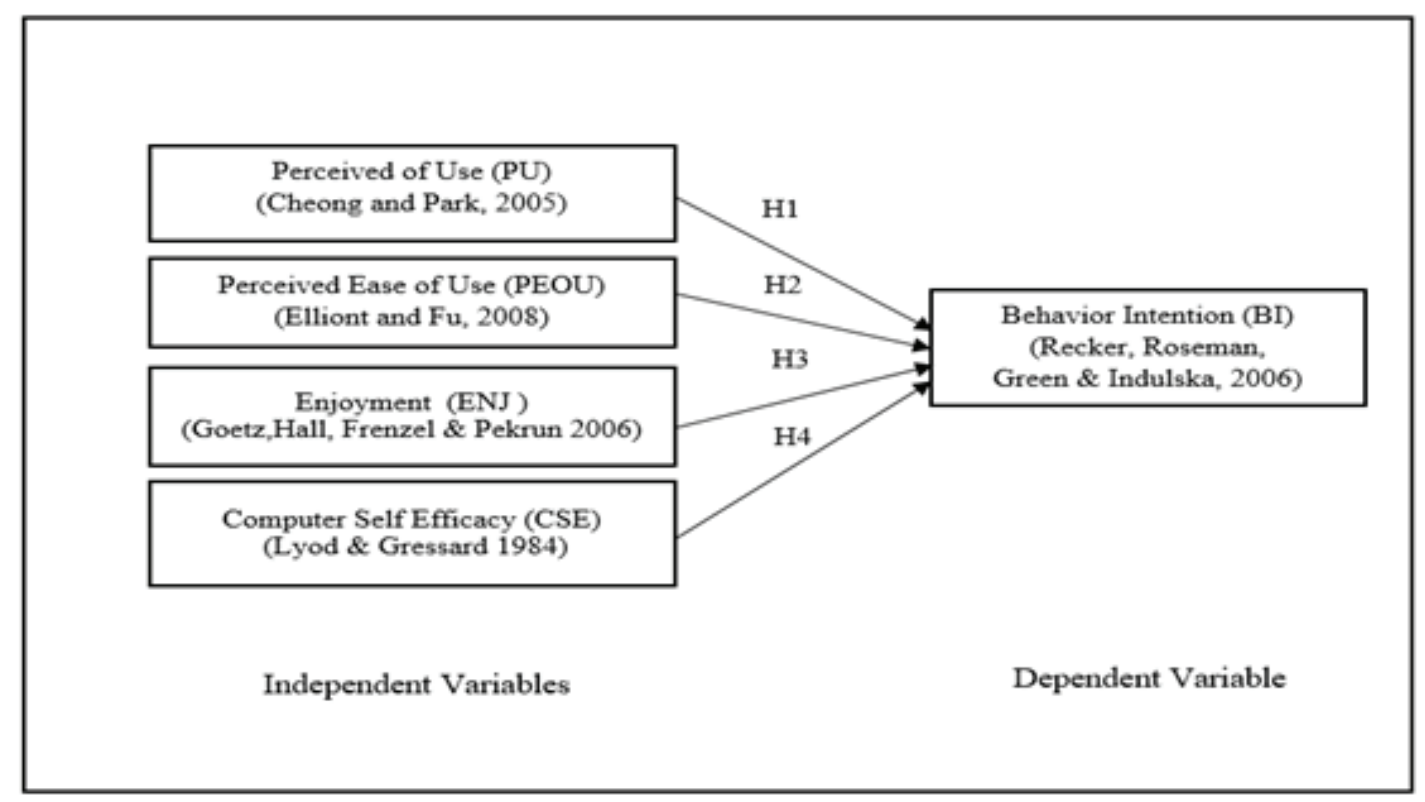

Figure 5: Proposed Framework.

\section{Method}

\subsection{Research design}

As this study seeks to identify the factors leading to behavioral intention to adopt online technology application at work place. Thus, a quantitative experimental design has been conducted to analyze the relationship between independent and dependent variables. Questionnaires are considered as the most appropriate method for data collection process [37]. The questionnaires were in the form of closed-ended. The arrangement of the questionnaires was set very simple and easy for the respondent to understand.

Data gathering method used in this research is non-probability sampling design. The non-probability sampling designs are fit into two categories; convenient and purposive sampling and this research used purposive sampling. The data was collected at PKNS offices in Shah Alam and Petaling Jaya. In this study, the size of the sample was 200 respondents who were the PKNS employees. The questionnaires were distributed to the employees from the two offices. Secondary data collection derived from the internet and other related journals to this research. This research has used an online database 
to search journals from the internet, for example, EBSCO and Emerald to find a related journal for this research.

The instrument was adapted from previous studies and developed from the dimension of the variables. The survey questionnaire was divided into five main sections. Section A is dealing with respondents' demographic profiles. Using nominal scale item, gender, age, profession, current service office, years of service, current servicing department, education background, and level of computer literacy. This information is needed to identify and measure to what extent do these variables have an impact on behavioral intention to adopt online technology application at work place. In section B, C, D, and $\mathrm{E}$, investigates mainly on dependent and independent variables. Respondents were asked to report their views based on the five type Likert scale ranging from 1, being with "Strongly Disagree" to 5 being "Strongly Agree". The questionnaires used English as the language medium for ease of understanding among Malaysian employees.

\subsection{Reliability test}

The internal consistency of the scale used, which is the reliability and validity of each item will be assessed using Cronbach Alpha. Cronbach Alpha is considered the most commonly accepted measure of reliability. The following table reports the Cronbach Alpha of the independent and dependent variables for this study. The variables for this study were reported to have excellent reliability with a coefficient of more than 0.7. According to Pallant [38], if Cronbach Alpha value is more than 0.7, which means that the data is reliable and if data is not reliable, appropriate action needs to be done on the questionnaire item.

TABLE 1: Reliability Statistics.

\begin{tabular}{|l|c|}
\hline Variables & $\begin{array}{c}\text { Cronbach's } \\
\text { Alpha }\end{array}$ \\
\hline Behavior Intention (DV) & .922 \\
\hline Perceived Usefulness (IV) & .975 \\
\hline Perceived Ease of Use (IV) & .682 \\
\hline Enjoyment (IV) & 0.79 \\
\hline Computer self-efficacy (IV) & 0.89 \\
\hline
\end{tabular}

\section{Results and Discussion}




\subsection{Descriptive analysis}

In this research, a total of 200 respondents were selected from PKNS offices. The whole data collection process took approximately 3 weeks. A total of 165 usable response questionnaires were accepted and coded for further analysis. Based on the 165 responses, the demographic characteristic of the respondents was split according to categories that include gender, age, profession, current service office, years of service, current servicing department, education background, and level of computer literacy.

\subsection{Demographic profile}

A summary of a demographic profile of 165 respondents is tabled below:

The data has been tested for normality and it represents a statistically normal distribution (Gravetter \& Wallnau, 2013) as depicted in Q-Q Plot and Boxplot.

\subsection{Pearson correlation analysis}

Based on Table 3.0 above, it is found that all values of $\mathrm{P}$ relating Behavioral Intention of using EWACS to each independent variable (of Perceived Usefulness, Perceived Ease of Use, Enjoyment and Computer Self Efficacy) indicated values of 0.000 which is less than 0.05. Similarly, Pearson Correlation Coefficient relating Behavioral Intention of using EWACS to each independent variable (of Perceived Usefulness, Perceived Ease of Use, Enjoyment and Computer Self Efficacy) indicated values exceeding 0.50. Thus, this indicates that there is a strong positive and significant correlation between each Independent Variables towards Dependent Variable.

Similar results were discovered by Nor Redzuan et al., [21], through their study on Electronic Human Resource Management (e-HRM) that proved Perceived Usefulness and Perceived Ease of Use are able to influence the intention of the employee to use e-HRM as the P-values were less than 0.05 in the Correlation Test. Meanwhile, the study by Alenezi, Karim and Veloo [25] too proved that there is a positive and small strength of the relationship between Perceived Usefulness and E-learning intention as it rejected the null hypothesis.

Findings by scholars of Bringula, Sarmiento, and Basa [39], Computer Self Efficacy was found to have a significant and positive relationship with electronic services usage as it influenced the usage. Meanwhile, result from the study by Sung and Yun [40] among others discovered that enjoyment was significantly affecting the Behavioral Intention in 
TABLE 2: Demographic Profile.

\begin{tabular}{|c|c|c|c|}
\hline Items & Description & Frequency & $\%$ \\
\hline \multirow[t]{2}{*}{ Gender } & Male & 92 & 55.8 \\
\hline & Female & 73 & 44.2 \\
\hline \multirow[t]{4}{*}{ Age } & 22 and below years old & 4 & 2.4 \\
\hline & 23 to 41 years old & 133 & 80.6 \\
\hline & 42 to 52 years old & 10 & 6.1 \\
\hline & 53 and above years old & 18 & 10.9 \\
\hline \multirow[t]{3}{*}{ Profession Category } & Kumpulan A (Pengurusan Tertinggi) & 40 & 24.2 \\
\hline & Kumpulan B (Pengurusan Dan Profesional) & 54 & 32.7 \\
\hline & Kumpulan C (Pelaksana $)$ & 71 & 43.0 \\
\hline \multirow[t]{3}{*}{ Current Servicing Office } & PKNS Wilayah Tengah (Headquarters) & 131 & 79.4 \\
\hline & PKNS Wilayah Utara & 22 & 13.3 \\
\hline & PKNS Wilayah Selatan & 12 & 7.3 \\
\hline \multirow[t]{5}{*}{ Year of Service } & Less thanl year & 12 & 7.3 \\
\hline & 1 to 3 years & 46 & 27.9 \\
\hline & 4 to 10 years & 61 & 37.0 \\
\hline & 11 to 20 years & 19 & 11.5 \\
\hline & More than 20 years & 27 & 16.4 \\
\hline \multirow[t]{5}{*}{ Current Servicing Department } & Sales Department & 15 & 9.1 \\
\hline & Technical Department & 61 & 37.0 \\
\hline & Finance Department & 13 & 7.9 \\
\hline & Administrative Department & 72 & 43.6 \\
\hline & Maintenance Department & 4 & 2.4 \\
\hline \multirow[t]{4}{*}{ Academic Education } & SPM & 16 & 9.7 \\
\hline & Certificate / Diploma & 67 & 40.6 \\
\hline & Bachelor & 55 & 33.3 \\
\hline & Master / $\mathrm{PhD}$. & 27 & 16.4 \\
\hline \multirow{3}{*}{$\begin{array}{l}\text { Level of Computer Literacy/ } \\
\text { Competency }\end{array}$} & Beginner & 14 & 8.5 \\
\hline & Intermediate & 109 & 66.1 \\
\hline & Advanced & 42 & 25.5 \\
\hline
\end{tabular}

their study on mobile multimedia use. This confirmed the journals by Davis et al., [19] that enjoyment was a significant determinant of behavioral intention to use computers in the workplace.

In terms of the relationship between independent variables, through Table 4.3 above, it is also shown that the relationship between each independent variable of Perceived Usefulness, Perceived Ease of Use, Enjoyment and Computer Self Efficacy also indicated a positive significance sign as all P-Values have a 0.000 value which is less than 0.05 . 
TABLE 3: Result of Correlations (**. Correlation is significant at the 0.01 level (2-tailed).).

\begin{tabular}{|c|c|c|c|c|c|c|}
\hline & & $\begin{array}{l}\text { Behavior } \\
\text { Intention }\end{array}$ & $\begin{array}{l}\text { Perceived } \\
\text { Usefulness }\end{array}$ & $\begin{array}{c}\text { Perceived } \\
\text { Ease of } \\
\text { Use }\end{array}$ & Enjoyment & $\begin{array}{l}\text { Computer } \\
\text { Self Efficacy }\end{array}$ \\
\hline \multirow[t]{3}{*}{$\begin{array}{l}\text { Behavior } \\
\text { Intertion }\end{array}$} & $\begin{array}{l}\text { Pearson } \\
\text { Correlation }\end{array}$ & 1 & $.721^{\circ}$ & $540^{\circ}$ & $.777^{* 0}$ & $.771^{\circ}$ \\
\hline & Sig. (2-tailed) & & .000 & .000 & .000 & .000 \\
\hline & $\mathbf{N}$ & 165 & 165 & 165 & 165 & 165 \\
\hline \multirow[t]{3}{*}{$\begin{array}{l}\text { Perceived } \\
\text { Usefulness }\end{array}$} & $\begin{array}{l}\text { Pearson } \\
\text { Correlation }\end{array}$ & $.721^{\circ}$ & 1 & $436^{\circ}$ & $.685^{\circ}$ & $.608^{\circ}$ \\
\hline & Sig. (2-tailed) & .000 & & .000 & .000 & .000 \\
\hline & $\mathrm{N}$ & 165 & 165 & 165 & 165 & 165 \\
\hline \multirow[t]{3}{*}{$\begin{array}{l}\text { Perceived } \\
\text { Ease of Use }\end{array}$} & $\begin{array}{l}\text { Pearson } \\
\text { Correlation }\end{array}$ & $.540^{\circ}$ & $.436^{\circ-}$ & 1 & $.623^{\circ}$ & $.583^{\circ}$ \\
\hline & Sig. (2-tailed) & .000 & .000 & & .000 & .000 \\
\hline & $\mathrm{N}$ & 165 & 165 & 165 & 165 & 165 \\
\hline \multirow[t]{3}{*}{ Erioyment } & $\begin{array}{l}\text { Pearson } \\
\text { Correlation }\end{array}$ & $.777^{\circ}$ & $.685^{\circ}$ & $.623^{\circ}$ & 1 & $.675^{\circ}$ \\
\hline & Sig. (2-tailed) & .000 & .000 & .000 & & .000 \\
\hline & $\mathbf{N}$ & 165 & 165 & 165 & 165 & 165 \\
\hline \multirow[t]{3}{*}{$\begin{array}{l}\text { Computer } \\
\text { Self Efficacy }\end{array}$} & $\begin{array}{l}\text { Pearson } \\
\text { Correlation }\end{array}$ & $.771^{-}$ & $.608^{-}$ & $.583^{\circ}$ & $.675^{\circ}$ & 1 \\
\hline & Sig. (2-tailed) & .000 & .000 & .000 & .000 & \\
\hline & $\mathrm{N}$ & 165 & 165 & 165 & 165 & 165 \\
\hline
\end{tabular}

\subsection{Analysis on open-ended questions}

Based on the responses, the result of the open-ended questions is given below according to each question:

\subsection{Describe how EWACS has helped you in your daily routines?}

Only $62 \%$ of respondents provided the answer to this question while remaining $38 \%$ chose either not to answer or answered with mixed and unrelated information. Out of this $62 \%$, based from the pattern of answer, it is discovered that: 
Easy to access information in EWACS

Easy to monitor information in EWACS

Easy to manage information in EWACS

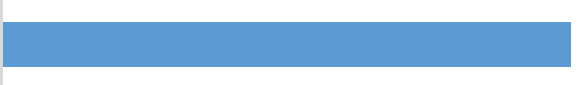

$48 \%$

$31 \%$

$21 \%$

Figure 6: Result of Open-Ended Question No. 1.

1. $48 \%$ believed that EWACS help their daily routines because it is easy to access the information within the system in terms of daily attendance records and monthly leave records.

2. $31 \%$ believed that using EWACS helped their daily routines because it is easy to monitor the information that relates to overall employee's attendance in each department and employee's movement in the office premise and branches.

3. $21 \%$ believed that using EWACS helped their daily routines because it is easy to manage the information that relate to employee's yearly performance in the organisation.

\subsection{What do you like most about EWACS?}

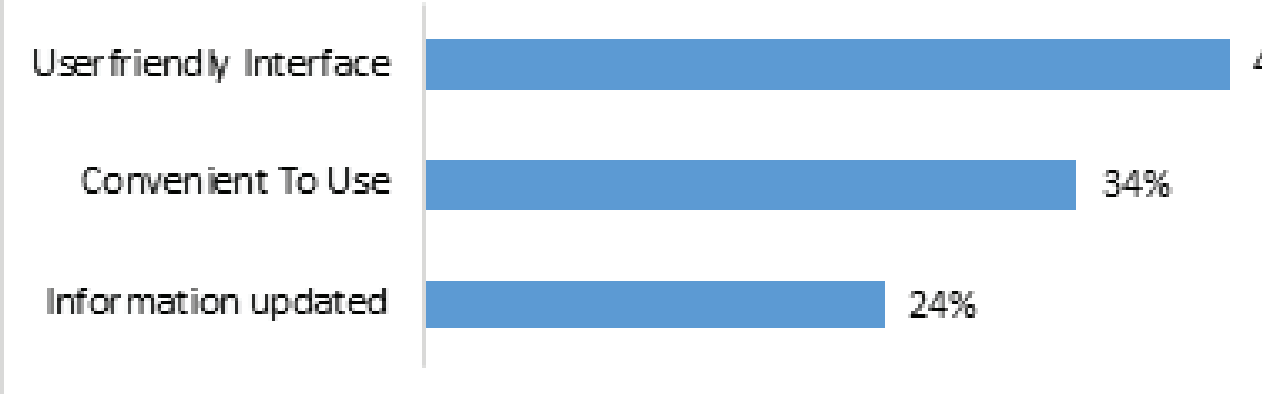

Figure 7: Result of Open-Ended Question No. 2.

Again, only $62 \%$ of respondents provided the answer to this question while remaining $38 \%$ chose either not to answer or answered with mixed and unrelated information. Out of this $62 \%$, based from the pattern of answer, it is discovered that: 
1. $42 \%$ reported that the most that they like about EWACS is the user-friendly interface. It consists of clarity, attractiveness, intuitive and consistent design of the system interface.

2. $34 \%$ reported the most they like about EWACS is the system convenient to use. The system reported for easy navigation, understandable and practical.

3. $24 \%$ reported the most they like about EWACS is information updating. Information that is related among employees in EWACS are employees' detail, employees monthly leave record and employee's daily attendance record.

\subsection{What do you dislike most about EWACS?}

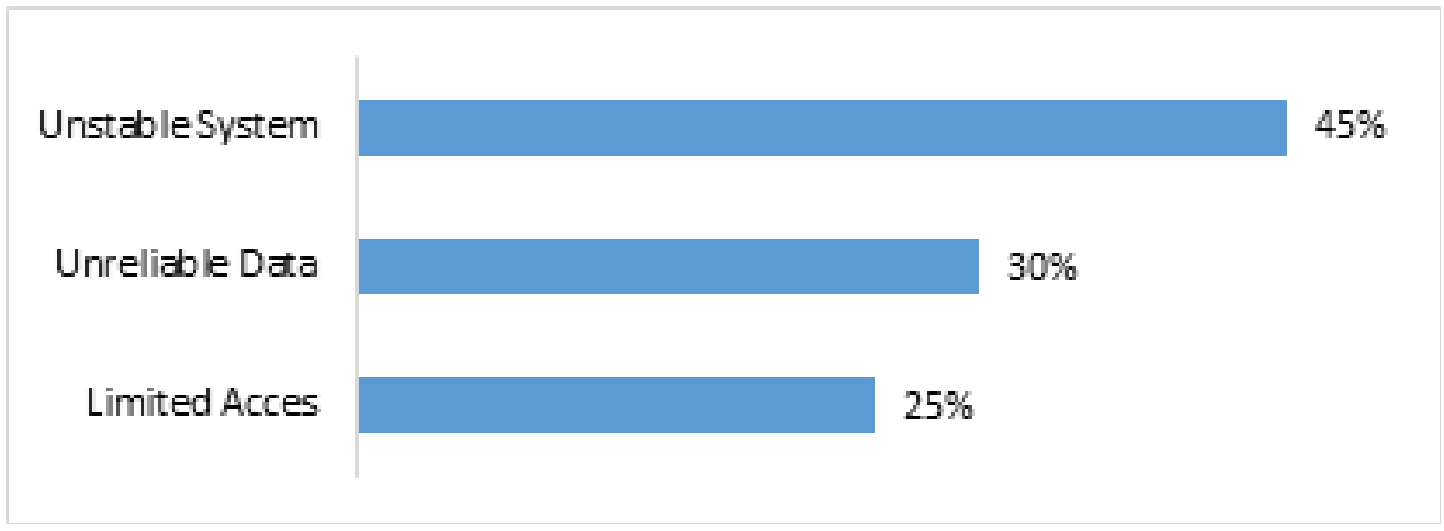

Figure 8: Result of Open-Ended Question No. 3.

Only $40 \%$ of respondents provided the answer to this question while remaining $60 \%$ chose either not to answer or answered with mixed and unrelated information. Out of this $40 \%$, based from the pattern of answer, it is discovered that:

1. From the total $40 \%$ from the respondents, $45 \%$ reported the most they dislike about EWACS is due to the unstable system. The unstable system according to respondents is about the system that is unable to respond with appropriate information when needed.

2. $30 \%$ reported the most they dislike about EWACS is due to the unreliable data. The unreliable data according to respondents is about the inaccurate data in certain EWACS modules.

$25 \%$ reported that they dislike most about EWACS is limited access. The limited access according to respondents is about the EWACS application accessibility is only in office 
premise. Some of respondents suggest the EWACS application accessibility should be from any location.

\section{Conclusion}

\subsection{Research implications and recommendations for further research}

The study showed that the employees' behavioral intention of adopting the electronic application is closely related to Perceived Usefulness, Perceived Ease of Use, Enjoyment and Computer Self Efficacy factors. The findings will assist the management to find a solution or intervention program to increase the adoption of EWACS in PKNS. This can increase the productivity level among employees in PKNS hence increase the company's performance. Furthermore, the research was conducted in a property developer company only and it may not be representative of other industries. Future research can identify the behavioral intentions among employees from other industries towards the adaptation of online technology at workplace.

\subsection{Contribution of the study}

Online technology application for the human resource department can enable the organization to improve labor productivity by performing human resource activities quicker than traditional practices and enabling non-HR employees to focus on core duties. EWACS through the electronic application of paperless working environment, less dependency on manual entry is available and this will decrease the reliance on paper for copying, printing and storing which turn out to be a reduction in cost. In the long run and from the environmental aspect, this directly preserves natural resources, prevent pollution and reduce wastage and energy for the sake of the future generation.

\subsection{Limitations of the study}

The present study was conducted among employees from property developer company alone instead of extending it to the other industries; this could give a different research finding. Moreover, due to the limited time, there was also a limitation on the number of sample size for this study. Thus, it was difficult to generalize all the information. 
In conclusion, this research aims to identify the factors contributing to behavioral intention towards adopting online technology application at workplace. The findings have highlighted that Perceived Usefulness, Perceived Ease of Use, Enjoyment and Computer Self-Efficacy are found to have significant relationship toward employee's behavioral intention. Thus, the implication of this research will be constructive for the management of PKNS or similar industry to strategize intervention programs for successful implementation towards adopting online technology application at work place.

\section{References}

[1] H. Ruël, \& Van der Kaap, H. E-HRM usage and value creation. Does a facilitating context matter? German Journal of Research in Human Resource Management, 26(3), 260-281, (2012).

[2] A. Salman, E.A. Choy, W.A. Wan Mahmud, \& R. Abdul Latif. Tracing the diffusion of internet in Malaysia: Then and now. Asian Social Science, 9(6), 9-15, (2013).

[3] F. A. Raja-Yusoff, R.N., Raja-Yusof, \& S. R. Hussin, S. R. Halal Supply Chain and Purchase Intention. International Journal of Economics and Management, 9 (S), p.155-172. (2015).

[4] N. Pfeffer. Theories in health care and research: Theories of race, ethnicity and culture. [Miscellaneous Article]. BMJ November 14, 317(7169), 1381-1384, (1998).

[5] V. Terzis, \& A. A. Economides. The acceptance and use of computer-based assessment. Computers and Education, 56(4), 1032-1044, (2011).

[6] S. Shrivastava, \& J.B. Shaw. Liberating HR through Technology. Human Resource Management, 42, 201-222. (2003).

[7] N. Iqbal, M. Ahmad, M. Allen, \& M.M. Raziq. Does e-HRM improve labour productivity? A study of commercial bank workplaces in Pakistan Employee Relations, Vol. 40 Issue: 2, pp.281-297, (2018).

[8] S. Sargolzaei. Developing Technology Acceptance Models for Decision Making in Urban Management. MOJ Civil Engineering, 2(6). (2017).

[9] E. Parry. An examination of e-HRM as a means to increase the value of the HR function. International Journal of Human Resource Management, 22(5), 1146-1162, (2011).

[10] E. Parry, \& S. Tyson. Desired goals and actual outcomes of e-HRM. Human Resource Management Journal, 21(3), 335-354, (2011).

[11] S. Strohmeier. Research in e-HRM: Review and Implications. Human Resource http: //dx.doi.org/10.1016/j.hrmr.2006.11.002. Management Review, 17, 19-37, (2007). 
[12] L. H. Al-Hmouze. The Impact of Electronic Human Resource Management Application on Organizational Performance,1-80, (2016).

[13] S. Ahmad. Technology in Organizations. International Journal of Research in Business Management, 2(7), 2321-886, (2014).

[14] M.S. Dohan, \& J. Tan. Perceived usefulness and behavioral intention to use consumer-oriented web-based health tools: a meta-analysis, (2013).

[15] A. M. Elkaseh, K.W. Wong, \& C.C. Fung. Perceived Ease of Use and Perceived Usefulness of Social Media for e-Learning in Libyan Higher Education: A Structural Equation Modeling Analysis. International Journal of Information and Education Technology, 6(3), 192-199, (2016).

[16] D. Abdullah, K. Jayaraman, D.N. Shariff, K.A. Bahari, \& N. M. Nor. The effects of perceived interactivity, perceived ease of use and perceived usefulness on online hotel booking intention: A conceptual framework. International Academic Research Journal of Social Science, 3(1), 16-23, (2017).

[17] X. Li, K. Ganeshan, \& G. Xu. The role of Social Networking Sites in e-learning. Proceedings - Frontiers in Education Conference. 1-6. 10.1109/FIE.2012.6462424. (2012).

[18] F. D. Davis. PhD Thesis - Massachusetts Institute of Technology. (1986).

[19] F. D. Davis. User Acceptance of Information Technology: System Characteristics, User Perceptions and Behavioral Impacts. International Journal of Man-Machine Studies, 38(3), 475-487, (1993).

[20] F. Abdullah, R. Ward, \& E. Ahmed. Investigating The Influence of The Most Commonly Used External Variables of TAM on Students' Perceived Ease of Use (PEOU) and Perceived Usefulness (PU) of e-portfolios. Computers in Human Behavior, 63, 7590, (2016).

[21] N. Nor Redzuan, N. Ahmad Razali, N. Muslim, \& W. Wan Hanafi. Studying Perceived in Usefulness and Perceived Ease of Use of Electronic Human Resource Management (e-HRM) with Behavior Intention. International Journal of Business Management (IJBM),1(2), 2016th ser., 118-131. (2016).

[22] K. Nusair, \& J. Kandampully. The antecedents of customer satisfaction with online travel services: a conceptual model. European Business Review, 20(1), 4-19, (2008).

[23] M.Y. Yi, \& Y. Hwang. Predicting the use of web-based information systems: selfefficacy, enjoyment, learning goal orientation, and the technology acceptance model. International J. Human-Computer Studies, 59(4), 431-599, (2003).

[24] T. Goetz, N. C. Hall, A.C. Frenzel, \& R.A. Pekrun. A hierarchical conceptualization of enjoyment in students. Learning and Instruction, 16(4), 323-338, (2006). 
[25] A.R. Alenezi, A.M. Karim, \& A. Veloo. An Empirical Investigation into The Role Of Enjoyment, Computer Anxiety, Computer Self-Efficacy And Internet Experience In Influencing The Students' Intention To Use E Learning: A Case Study From Saudi Arabian Governmental Universities. Turkish Online Journal of Educational Technology, 9(4), 22-34, (2010).

[26] V. Bhatiasevi. Acceptance of e-learning for users in higher education: An extension of the technology acceptance model. Social Sciences, 6(6), 513-520, (2011).

[27] I. Brown, G. Cheung, K. Chan, \& K. Wan. Teachers' Knowledge and Technology Acceptance: A Study on the Adoption of Clickers. In proceedings of the 11th International Conference on e-Learning (ICEL 2016) (pp. 46-51), (2016).

[28] S.Y. Park. An Analysis of the Technology Acceptance Model in Understanding University Students' Behavioral Intention to Use e-Learning. Educational Technology \& Society, 12(3), 150-162, (2009).

[29] S. Jia, \& L.B. Eder. Exploring Intentions to Virtual World for Business. Journal of Electronic Commerce Research, 10(2), 94-103, (2009).

[30] J. H. Al-Ammary, A.K. Al-Sherooqi, \& H.K. Al-Sherooqi. The Acceptance of Social Networking as a Learning Tools at University of Bahrain. International Journal of Information and Education Technology, 4(2), 208-214, (2014).

[31] M. K. Chow, H. D. Herold, T. M. Choo, \& K. Chan. Extending the technology acceptance model to explore the intention to use second life for enhancing healthcare education. Computers \& Education, 59(4), 1136-1144, (2012).

[32] N. F.A. Al-Mushasha. Determinants of e-Learning Acceptance in Higher Education Environment Based on Extended Technology Acceptance Model. In 2013 Fourth International Conference on e-Learning "Best Practices in Management, Design and Development of e-Courses: Standards of Excellence and Creativity" (pp.261-266). IEE, (2013).

[33] C. Ma, C. Chao, \& B. Cheng. Integrating technology acceptance model and tasktechnology fit into blended E-learning system. Journal of Applied Sciences, 13(5), 736-742, 2013. DOI: 10.3923/jas.2013.736.742

[34] F. Davis, R. Bagozzi, \& P. Warshaw. User acceptance of computer technology: A comparison of two theoretical models, Management Science, 35, 8, 982-1003, 1989.

[35] V. Venkatesh, \& H. Bala. Technology acceptance model 3 and a research agenda on interventions. Decision Sciences, 39, 273-315, 2008.

[36] I. F. Liu, M. C. Chen, Y.S. Sun, D. Wible, \& C.A. Kuo. Extending the TAM model to explore the factors that affect intention to use an online learning community. Computers and Education, 54, 600-610, 2010. 
[37] E. Taylor-Powell, \& C. Hermann. Collecting evaluation data: Surveys (University of Wisconsin. Publication no. G3658-10), 2000. Retrieved from: http://learningstore.uwex.edu/assets/pdfs/G3658-10.PDF.

[38] J. Pallant. SPSS survival manual. A step by step guide to data analysis using SPSS for windows (version 12). 2nd Edition, Open University Press, New York, 2005.

[39] P. B. Rex, J. M. Julius, Sarmiento \& S. B. Roselle. Computer Self-efficacy and Its Relationship with Web Portal Usage: Evidence from the University of the East. International Journal of Computing Sciences Research, 2017, Vol. 1, Issue 1, 24-29, 2017.

[40] J. Sung, \& Y. Yun. Toward a more robust usability concept with perceived enjoyment in the context of mobile multimedia service. International Journal of Human Computer Interaction, 1(2), 12- 32, 2010. 